Supplement of Solid Earth, 12, 563-580, 2021 https://doi.org/10.5194/se-12-563-2021-supplement

(C) Author(s) 2021. This work is distributed under the Creative Commons Attribution 4.0 License.

(c) (1)

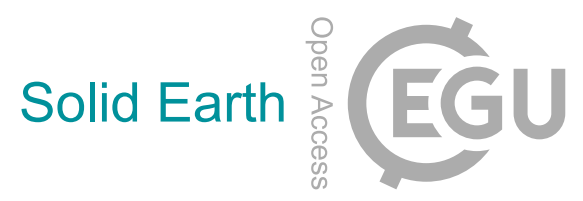

Supplement of

\title{
Contrasting exhumation histories and relief development within the Three Rivers Region (south-east Tibet)
}

Xiong Ou et al.

Correspondence to: Xiong Ou (xiong.ou@univ-grenoble-alpes.fr) and Anne Replumaz (anne.replumaz@univ-grenoble-alpes.fr)

The copyright of individual parts of the supplement might differ from the CC BY 4.0 License. 


\section{Supplementary material: low-temperature thermochronology data and thermo-kinematic modeling}

\section{Data set:}

We selected a dataset composed of 11 samples from BaimaXueshan massif and 6 samples from Kawagebo massif with AHe,

5 AFT and ZHe ages from Yang et al. (2016), Liu-Zeng et al. (2018) and Replumaz et al. (2020), with details shown in Table $\mathrm{S} 1$ below. All the samples are collected from granite or granitoid intrusion or massif. To note that the altitude for each samples is re-acquired from GoogleEarth by using their original GPS coordinates because of important approximation and inaccuracy of the given altitude in references. For fission tracks analyses on apatite, a minimum of 20 grains have been counted for Yang et al. (2016), 29 grains for Liu-Zeng et al. (2018) and 16 grains for Replumaz et al. (2020).

\begin{tabular}{|c|c|c|c|c|c|c|c|c|c|c|c|}
\hline $\begin{array}{c}\text { Sample } \\
\text { name }\end{array}$ & Longitude & Latitude & $\begin{array}{l}\text { Elevation } \\
\quad \text { (m) }\end{array}$ & $\begin{array}{c}\text { AHe } \\
\text { age } \\
\text { (Ma) }\end{array}$ & $\begin{array}{c}1 \sigma \\
\text { error } \\
\text { (Ma) }\end{array}$ & $\begin{array}{c}\text { Weighted } \\
\text { mean age } \\
\text { (Ma) }\end{array}$ & $\begin{array}{c}\text { AFT } \\
\text { age } \\
(\mathrm{Ma} \pm 1 \sigma)\end{array}$ & $\begin{array}{c}\mathrm{ZHe} \\
\text { age } \\
\text { (Ma) }\end{array}$ & $\begin{array}{c}1 \sigma \\
\text { error } \\
\text { (Ma) }\end{array}$ & $\begin{array}{c}\text { Weighted } \\
\text { mean age } \\
\text { (Ma) }\end{array}$ & Reference \\
\hline \multicolumn{12}{|c|}{ BaimaXueshan } \\
\hline DQ01-1 & 98.9616 & 28.3796 & 4944 & 19.1 & 0.9 & $18.9 \pm 1.0$ & $56.6 \pm 2.8$ & 72.9 & 1.0 & $93 \pm 23$ & \multirow{21}{*}{$\begin{array}{l}\text { Liu-Zeng et } \\
\text { al., } 2018\end{array}$} \\
\hline DQ01-2 & & & & 18.4 & 1.6 & & & 102.2 & 1.8 & & \\
\hline DQ01-3 & & & & 19.0 & 0.7 & & & 104.4 & 1.9 & & \\
\hline DQ03-1 & 98.9687 & 28.3727 & 4553 & 12.0 & 1.2 & $16.4 \pm 3.8$ & $39.3 \pm 2.2$ & 97.6 & 1.3 & $97 \pm 11$ & \\
\hline DQ03-2 & & & & 18.3 & 1.2 & & & 105.8 & 1.4 & & \\
\hline DQ03-3 & & & & 18.8 & 0.9 & & & 88.7 & 1.2 & & \\
\hline DQ04-1 & 98.972 & 28.3829 & 4548 & 15.5 & 1.3 & $16.4 \pm 1.5$ & & 113.0 & 1.7 & $111 \pm 2$ & \\
\hline DQ04-2 & & & & 15.5 & 1.6 & & & 110.1 & 1.7 & & \\
\hline DQ04-3 & & & & 17.7 & 1.2 & & & 109.9 & 1.7 & & \\
\hline DQ11-1 & 98.9263 & 28.3753 & 4228 & 12.1 & 0.4 & $8.75 \pm 0.3$ & $43.8 \pm 2.6$ & 97.8 & 1.5 & $93 \pm 13$ & \\
\hline DQ11-2 & & & & 8.8 & 0.1 & & & 81.7 & 1.3 & & \\
\hline DQ11-3 & & & & 8.7 & 0.3 & & & 100.2 & 1.6 & & \\
\hline DQ13-1 & 98.9176 & 28.3762 & 3929 & 9.7 & 0.4 & $9.5 \pm 3.4$ & $43.8 \pm 2.1$ & 98.0 & 2.0 & $103.9 \pm 6.7$ & \\
\hline DQ13-2 & & & & 6.8 & 0.7 & & & 106.1 & 1.8 & & \\
\hline DQ13-3 & & & & 12.2 & 0.9 & & & 107.6 & 1.9 & & \\
\hline DQ15-1 & 98.9091 & 28.3797 & 3641 & 8.9 & 0.4 & $8.6 \pm 1.0$ & $39.4 \pm 2.1$ & 90.5 & 1.6 & $85.1 \pm 7.3$ & \\
\hline DQ15-2 & & & & 9.1 & 0.3 & & & 79.4 & 1.4 & & \\
\hline DQ15-3 & & & & 7.8 & 0.1 & & & 85.8 & 1.5 & & \\
\hline DQ17-1 & 98.9091 & 28.3797 & 3641 & 4.7 & 0.4 & $6.2 \pm 1.7$ & $28.6 \pm 1.5$ & 87.0 & 1.5 & $78.6 \pm 9.5$ & \\
\hline DQ17-2 & & & & 6.83 & 0.5 & & & 73.1 & 1.0 & & \\
\hline DQ17-3 & & & & 7.0 & 0.5 & & & 75.9 & 1.1 & & \\
\hline
\end{tabular}




\begin{tabular}{|c|c|c|c|c|c|c|c|c|c|c|c|}
\hline $\begin{array}{l}\text { LT18-1 } \\
\text { LT18-2 }\end{array}$ & 98.9025 & 28.3482 & 2873 & & & & $15.3 \pm 1.1$ & & & & \\
\hline $\begin{array}{l}\text { LT19-1 } \\
\text { LT19-2 }\end{array}$ & 98.9051 & 28.3903 & 3024 & & & & $21.0 \pm 1.2$ & & & & \\
\hline MK01-1 & 98.9054 & 28.4128 & 2953 & 5.12 & 0.07 & $5.8 \pm 0.5$ & & 87.05 & 0.66 & $90.68 \pm 7.12$ & Yang et al. \\
\hline MK01-2 & & & & 5.49 & 0.06 & & & 104.41 & 0.46 & & 2016 \\
\hline MK01-3 & & & & 5.69 & 0.06 & & & & & & \\
\hline MK01-4 & & & & 4.64 & 0.05 & & & 80.57 & 0.85 & & \\
\hline MK01-5 & & & & 6.76 & 0.07 & & & & & & \\
\hline MK01-6 & & & & 7.37 & 0.06 & & & & & & \\
\hline MK08-1 & 98.9054 & 28.4128 & 2953 & 4.31 & 0.09 & $4.3 \pm 0.3$ & $13.5 \pm 1.3$ & 81.84 & 0.80 & $84.35 \pm 1.03$ & \\
\hline MK08-2 & & & & 4.87 & 0.06 & & & 83.62 & 0.68 & & \\
\hline MK08-3 & & & & 3.95 & 0.06 & & & 86.50 & 0.58 & & \\
\hline MK08-4 & & & & 4.26 & 0.05 & & & 85.43 & 0.34 & & \\
\hline MK08-5 & & & & 4.96 & 0.07 & & & & & & \\
\hline MK08-6 & & & & 3.28 & 0.05 & & & & & & \\
\hline
\end{tabular}

\section{Kawagebo}

\begin{tabular}{|c|c|c|c|c|c|c|c|c|c|c|c|}
\hline KW40-1 & 98.7660 & 28.2013 & 2911 & & & & $6.1 \pm 2.5$ & & & & \multirow{16}{*}{$\begin{array}{c}\text { Replumaz et } \\
\text { al., } 2020\end{array}$} \\
\hline KW41-2 & \multirow[t]{3}{*}{98.7776} & \multirow[t]{3}{*}{28.2063} & \multirow[t]{3}{*}{2701} & 3.2 & 0.3 & \multirow[t]{3}{*}{$2.7 \pm 0.8$} & \multirow[t]{3}{*}{$5.6 \pm 1.0$} & & & & \\
\hline KW41-4 & & & & 3.1 & 0.3 & & & & & & \\
\hline KW41-6 & & & & 2.1 & 0.2 & & & & & & \\
\hline KW42-1 & \multirow[t]{4}{*}{98.7888} & \multirow[t]{4}{*}{28.2022} & \multirow[t]{4}{*}{2555} & 3.0 & 0.3 & \multirow[t]{4}{*}{$2.9 \pm 1.2$} & \multirow[t]{4}{*}{$3.0 \pm 0.8$} & & & & \\
\hline KW42-2 & & & & 2.8 & 0.3 & & & & & & \\
\hline KW42-3 & & & & 2.0 & 0.2 & & & & & & \\
\hline KW42-4 & & & & 3.8 & 0.3 & & & & & & \\
\hline KW43-3 & \multirow[t]{4}{*}{98.7776} & \multirow[t]{4}{*}{28.2063} & \multirow[t]{4}{*}{2701} & 1.2 & 0.11 & \multirow[t]{4}{*}{$1.5 \pm 0.4$} & \multirow[t]{4}{*}{$3.2 \pm 1.2$} & & & & \\
\hline KW43-4 & & & & 1.7 & 0.16 & & & & & & \\
\hline KW43-5 & & & & 1.59 & 0.14 & & & & & & \\
\hline KW43-6 & & & & 1.52 & 0.14 & & & & & & \\
\hline KW52-1 & \multirow[t]{4}{*}{98.8503} & \multirow[t]{4}{*}{28.1982} & \multirow[t]{4}{*}{2224} & 1.16 & 0.1 & \multirow[t]{4}{*}{$1.2 \pm 0.2$} & & & & & \\
\hline KW52-2 & & & & 1.09 & 0.1 & & & & & & \\
\hline KW52-3 & & & & 1.29 & 0.12 & & & & & & \\
\hline KW52-4 & & & & 1.1 & 0.1 & & & & & & \\
\hline MK04-1 & \multirow[t]{2}{*}{98.8592} & \multirow[t]{2}{*}{28.2648} & \multirow[t]{2}{*}{2066} & 1.65 & 0.04 & \multirow[t]{2}{*}{$1.3 \pm 0.3$} & & 8.17 & 0.05 & \multirow[t]{2}{*}{$7.65 \pm 0.53$} & \multirow{2}{*}{$\begin{array}{c}\text { Yang et al., } \\
2016\end{array}$} \\
\hline MK04-2 & & & & 1.01 & 0.02 & & & 7.12 & 0.07 & & \\
\hline
\end{tabular}

Table S1: Dataset of single-grain apatite (U-Th)/He, apatite fission track and zircon (U-Th)/He ages. For AHe and ZHe ages, the 1-sigma error has been defined using the standard deviation of the replicate analyses divided by $n-1$ where $n$ represents the number of replicate. The weighted mean calculations were made using Isoplot/Ex_ver3 (Ludwig, 2003), weighted by age uncertainties of individual grains. For

15 AFT ages from Yang et al., (2016), ages are pooled ages and were calculated using the recommended $\zeta$ calibration approach (Hurford and Green, 1983). For AFT ages from Liu-Zeng et al., (2018), ages are pooled age if $\mathrm{P}\left(\chi^{2}\right)>5 \%$ and are central age if $\mathrm{P}\left(\chi^{2}\right)<5 \%$. For AFT age from Replumaz et al., (2020), ages are reported as central ages with $1 \sigma$ uncertainty, as well as upper and lower $95 \%$ confidence intervals. 


\section{Thermo-kinematic modelling:}

The thermo-kinematic modeling code Pecube (Braun et al., 2012) is based on a mixed Eulerian-Lagrangian approach and

20 this finite-element model predicts the thermal structure of a crustal block and thermochronological cooling ages at the surface following an imposed kinematic and topographic histories. Pecube solves the 3D heat-transport equation during exhumation using an empirical mathematical model for fission-track annealing and analytical diffusion models for isotopebased thermochronometers (Braun et al., 2012).

The upper boundary condition of the crustal block is the topography given by a global $900 \mathrm{~m}$ resolution DEM or a user

25 defined topography modified from the present-day one (using amplification factors or offsets) or theorical one (constant elevation or sinusoidal etc...). Isostatic compensation is influential only in narrow river gorges and has been constrained to be less than $50 \mathrm{~m}$ in the SE Tibetan Plateau (Clark et al., 2006). Isostatic rebound is known to be negligible on the increase of the plateau elevation and is not taken into account in our models. The block bears a thickness of $50 \mathrm{~km}$ as defined for the Eastern Tibetan plateau (Yao et al., 2008), with a basal temperature at $900^{\circ} \mathrm{C}$ (Wang Yang, 2012) corresponding to a thermal

30 gradient of $\sim 20^{\circ} \mathrm{C} / \mathrm{km}$. Thermal properties such as rock conductivity heat capacity density and heat production are spatially uniform and constant through time and are given by default values from Pecube code. A basic scenario is characterized by one or several exhumation phases and corresponding exhumation velocities for each phase, which are assumed to be spatially uniform but variable through time. Worthy note is that the implementation of a fault could spatially differentialize the velocity resulting in continuous motion of one part of the crustal block along the fault, the rest being tectonically

35 quiescent. The fault trace at the surface could be fixed with two points of given coordinates in an orthonormal reference frame and the number of fault segments at depth separated by inflection points, along with the maximum depth of the fault need to be fixed too.

A two-step neighbourhood algorithm inversion (Sambridge, 1999a, b) method is used to obtain the most suitable parameters. In the "sampling" stage, the model explores efficiently the multi-dimensional parameter space to derive optimal (best-fit)

40 parameter values and corresponding smallest misfit through a comparison of measured and predicted thermochronological ages. In our study, an ensemble of 10,000 forward models, which is composed of 20 iterations of 500 models each, with subsequent iterations resampling the parameter space of the previous iteration, was performed. The resampling ratio from previous iteration is fixed to $90 \%$ to avoid convergence in local minima. No strict rules are applied to define the total number of forward models, but generally a more complex scenario with more parameters to invert needs more iterations and more

45 forward models. In the "appraisal" stage, the model ensemble generated form the first stage is resampled statistically to gain Bayesian estimates of the precision with which the different parameters are resolved. This phase yields a 1D and 2D marginal posterior probability-density function (pdf) of the parameter values, from which a "most likely" value and its standard deviation can be inferred (Braun et al., 2012). 


\section{Results:}

50 For BaimaXueshan massif, we modelled some complex scenarios with three or four exhumation phases and specified transition times, in order to confirm if a rapid exhumation phase around $40 \mathrm{Ma}$, as speculated by Liu-Zeng et al. (2018). The best-fitting of these models turns to be a four-phase scenario (Table 2, Fig. S1), with a relatively low misfit (3.13), and it shows quite well constrained parameters from pdf's (Fig. S2). However, this model is composed of protracted slow exhumation preceding an acceleration in the last few Myr, which is almost equivalent to the two-phase exhumation scenario.

55 And no rapid exhumation phase around $40 \mathrm{Ma}$ has been resolved. Its age-elevation profile resemble to that of two-phase exhumation scenario too (see in article).

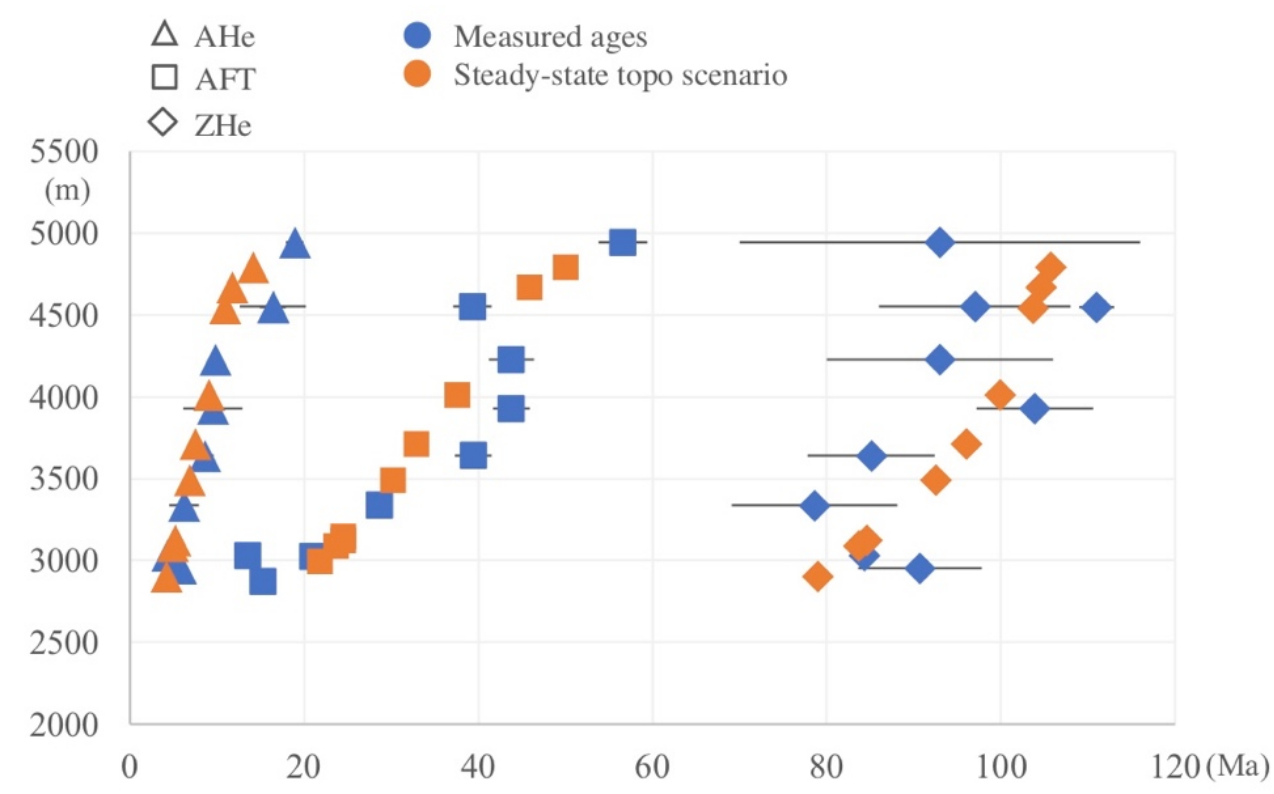

60 Figure S1: Pecube modelling result for the BaimaXueshan massif, showing an age-elevation profile of measured (solid blue symbols; triangles, squares and diamonds corresponding to AHe, AFT and ZHe ages respectively) and predicted (solid orange symbols) ages for a steady-state topography scenario of four exhumation phases. 
(a)

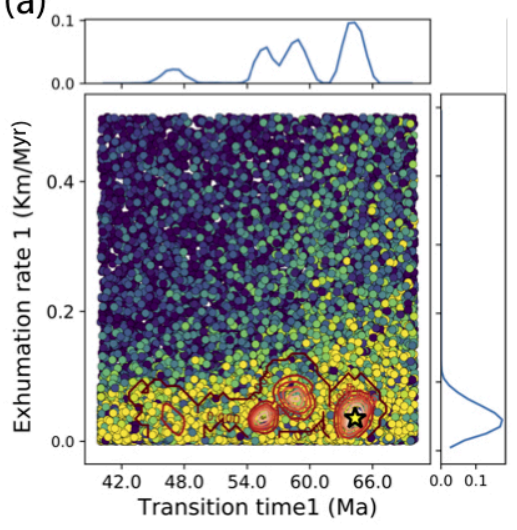

(c)

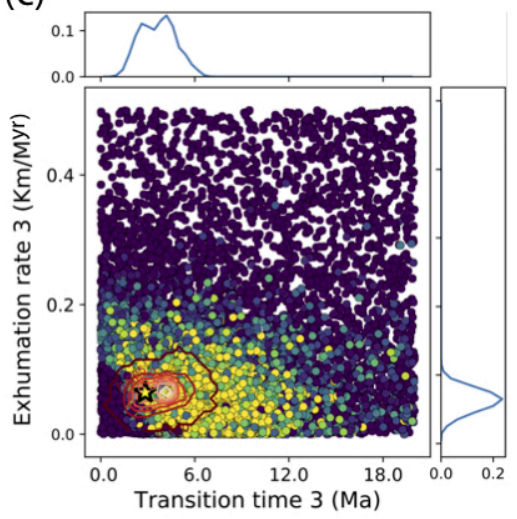

(b)

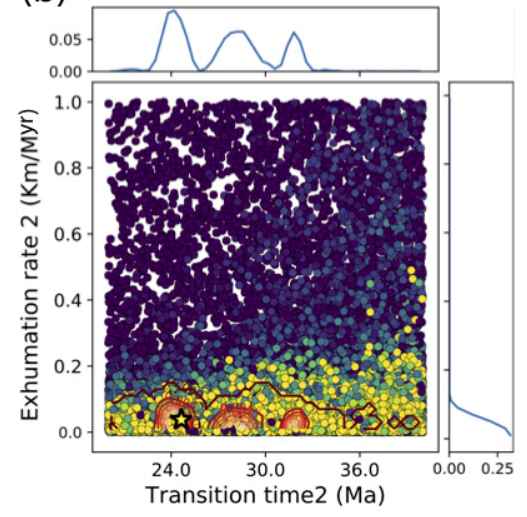

(d)

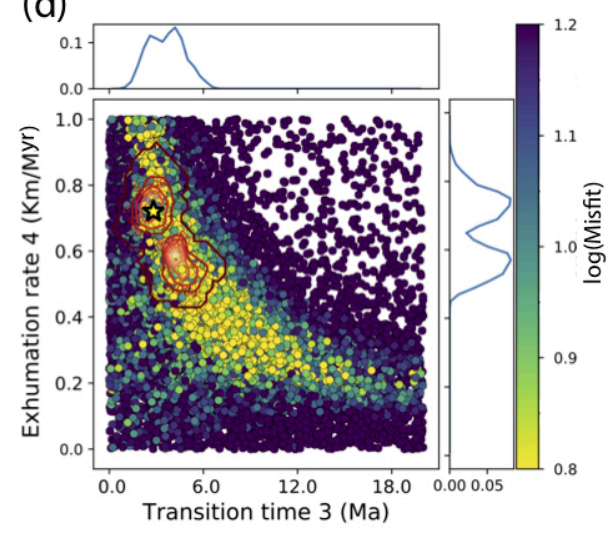

Figure S2: Scatterplots of Pecube inversion misfits for the steady-state scenario of four exhumation phases (orange signs in Figure S1) for

65 the BaimaXueshan massif. Coloured dots represent individual forward-model runs plotted in 2-dimensional projections of the parameter space, with colours corresponding to misfit values, shown on a log scale. Posterior probability density functions for parameter values are plotted along the axes. The best-fit solution is represented by a yellow star with $2 \sigma$ (dark red) and $1 \sigma$ (light red) confidence contours. (a) Transition time 1 (between first and second exhumation phase) versus exhumation rate during the first phase. (b) Transition time 2 versus exhumation rate during the second phase. (c) Transition time 3 versus exhumation rate during the third phase. (d) Transition time 3 versus exhumation rate during the fourth phase.

\section{References}

Braun J, van der Beek P, Valla P, Robert X, Herman F, Glotzbach C, Pedersen V, Perry C, Simon-Labric T, Prigent C.: Quantifying rates of landscape evolution and tectonic processes by thermochronology and numerical modeling of crustal heat transport using PECUBE, Tectonophysics, 524-525: 1-28, https://doi.org/10.1016/j.tecto.2011.12.035, 2012. 
75 Clark, M. K., Royden, L. H., Whipple, K. X., Burchfiel, B. C., Zhang, X. and Tang, W.: Use of a regional, relict landscape to measure vertical deformation of the eastern Tibetan Plateau, J. Geophys. Res., 111(F03002), https://doi.org/10.1029/2005JF000294, 2006.

Hurford, A., J., and Green, P., F.: The zeta age calibration of fission-track dating, Chemical Geology, 41, 285-317, https://doi.org/10.1016/S0009-2541(83)80026-6, 1983.

80 Liu-Zeng, J., Zhang, J., McPhillips, D., Reiners, P., Wang, W., Pik, R., Zeng, L., Hoke, G., Xie, K., Xiao, P., Zheng, D. and Ge, Y.: Multiple episodes of fast exhumation since Cretaceous in southeast Tibet, revealed by low-temperature thermochronology, Earth Planet. Sci. Lett., 490, 62-76, https://doi.org/10.1016/j.epsl.2018.03.011, 2018.

Ludwig, K.,: User's Manual for Isoplot 3.00: A Geochronological Toolkit for Microsoft Excel, Berkeley Geochronology Center, Berkeley, USA, 2003.

85 Replumaz, A., San José, M., Margirier, A., van der Beek, P., Gautheron, C., Leloup, P. H., et al.: Tectonic control on rapid late Miocene-Quaternary incision of the Mekong River knickzone, Southeast Tibetan Plateau, Tectonics, 39, e2019TC005782, https://doi.org/10.1029/2019TC005782, 2020.

Sambridge, M.: Geophysical inversion with a neighbourhood algorithm --I. Searching a parameter space, Geophys. J. Int., 138, 479-494, https://doi.org/10.1046/j.1365-246X.1999.00876.x, 1999a.

90 Sambridge, M.: Geophysical inversion with a neighbourhood algorithm -- II. Appraising the ensemble, Geophys. J. Int., 138, 727-746, https://doi.org/10.1046/j.1365-246x.1999.00900.x,1999b.

Wang, Y.: A preliminary study on the lithospheric thermal structure and rheology of the Tibetan plateau, Earthq. Sci., 25, 399-408, https://doi.org/10.1007/s11589-012-0865-z, 2012.

Yang, R., Fellin, M. G., Herman, F., Willett, S. D., Wang, W., \& Maden, C.: Spatial and temporal pattern of erosion in the Three Rivers Region, southeastern Tibet, Earth Planet. Sci. Lett., 433, 10-20, https://doi.org/10.1016/j.epsl.2015.10.032, 2016.

Yao, H., van der Hilst, R. D., and Montagner, J.-P.: Heterogeneity and anisotropy of the lithosphere of SE Tibet from surface wave array tomography, J. Geophys. Res., 115, B12307, https://doi.org/10.1029/2009JB007142, 2010. 